\title{
Nitrogen resorption in Acer platanoides and Acer saccharum : influence of light exposure and leaf pigmentation
}

\section{Duan, Baoli}

2014-11

Duan , B , Paquette , A , Juneau , P , Brisson , J , Fontaine , B \& Berninger , F A 2014 , ' Nitrogen resorption in Acer platanoides and Acer saccharum : influence of light exposure and leaf pigmentation ' , Acta Physiologiae Plantarum , vol. 36 , no. 11 , pp. 3039-3050 . https://doi.org/10.1007/s11

http://hdl.handle.net/10138/159373

https://doi.org/10.1007/s11738-014-1674-x

acceptedVersion

Downloaded from Helda, University of Helsinki institutional repository.

This is an electronic reprint of the original article.

This reprint may differ from the original in pagination and typographic detail.

Please cite the original version. 
Dear Author,

\section{Springer}

Here are the proofs of your article.

- You can submit your corrections online, via e-mail or by fax.

- For online submission please insert your corrections in the online correction form. Always indicate the line number to which the correction refers.

- You can also insert your corrections in the proof PDF and email the annotated PDF.

- For fax submission, please ensure that your corrections are clearly legible. Use a fine black pen and write the correction in the margin, not too close to the edge of the page.

- Remember to note the journal title, article number, and your name when sending your response via e-mail or fax.

- Check the metadata sheet to make sure that the header information, especially author names and the corresponding affiliations are correctly shown.

- Check the questions that may have arisen during copy editing and insert your answers/ corrections.

- Check that the text is complete and that all figures, tables and their legends are included. Also check the accuracy of special characters, equations, and electronic supplementary material if applicable. If necessary refer to the Edited manuscript.

- The publication of inaccurate data such as dosages and units can have serious consequences. Please take particular care that all such details are correct.

- Please do not make changes that involve only matters of style. We have generally introduced forms that follow the journal's style.

Substantial changes in content, e.g., new results, corrected values, title and authorship are not allowed without the approval of the responsible editor. In such a case, please contact the Editorial Office and return his/her consent together with the proof.

- If we do not receive your corrections within $\mathbf{4 8}$ hours, we will send you a reminder.

- Your article will be published Online First approximately one week after receipt of your corrected proofs. This is the official first publication citable with the DOI. Further changes are, therefore, not possible.

- The printed version will follow in a forthcoming issue.

\section{Please note}

After online publication, subscribers (personal/institutional) to this journal will have access to the complete article via the DOI using the URL: http://dx.doi.org/[DOI].

If you would like to know when your article has been published online, take advantage of our free alert service. For registration and further information go to: http://www.link.springer.com.

Due to the electronic nature of the procedure, the manuscript and the original figures will only be returned to you on special request. When you return your corrections, please inform us if you would like to have these documents returned. 


\section{Metadata of the article that will be visualized in OnlineFirst}

\begin{tabular}{|c|c|c|}
\hline ArticleTitle & \multicolumn{2}{|c|}{$\begin{array}{l}\text { Nitrogen resorption in Acer platanoides and Acer saccharum: influence of light exposure and leaf } \\
\text { pigmentation }\end{array}$} \\
\hline \multicolumn{3}{|l|}{ Article Sub-Title } \\
\hline Article CopyRight & \multicolumn{2}{|c|}{$\begin{array}{l}\text { Franciszek Górski Institute of Plant Physiology, Polish Academy of Sciences, Kraków } \\
\text { (This will be the copyright line in the final PDF) }\end{array}$} \\
\hline Journal Name & \multicolumn{2}{|c|}{ Acta Physiologiae Plantarum } \\
\hline \multirow[t]{11}{*}{ Corresponding Author } & Family Name & Duan \\
\hline & Particle & \\
\hline & Given Name & Baoli \\
\hline & Suffix & \\
\hline & Division & Département des sciences biologiques, CP 8888 Succ, Centre-ville \\
\hline & Organization & Université du Québec à Montréal \\
\hline & Address & Montréal, QC, H3C 3P8, Canada \\
\hline & Division & Key Laboratory of Mountain Surface Processes and Ecological Regulation \\
\hline & Organization & $\begin{array}{l}\text { Institute of Mountain Hazards and Environment, Chinese Academy of } \\
\text { Sciences }\end{array}$ \\
\hline & Address & Chengdu, 610041, China \\
\hline & Email & duanbl@imde.ac.cn \\
\hline \multirow[t]{8}{*}{ Author } & Family Name & Paquette \\
\hline & Particle & \\
\hline & Given Name & Alain \\
\hline & Suffix & \\
\hline & Division & Center for Forest Research (CFR) \\
\hline & Organization & Université du Québec à Montréal \\
\hline & Address & Montréal, QC, H3C 3P8, Canada \\
\hline & Email & \\
\hline \multirow[t]{8}{*}{ Author } & Family Name & Juneau \\
\hline & Particle & \\
\hline & Given Name & Philippe \\
\hline & Suffix & \\
\hline & Division & Département des sciences biologiques, CP 8888 Succ, Centre-ville \\
\hline & Organization & Université du Québec à Montréal \\
\hline & Address & Montréal, QC, H3C 3P8, Canada \\
\hline & Email & \\
\hline \multirow[t]{8}{*}{ Author } & Family Name & Brisson \\
\hline & Particle & \\
\hline & Given Name & Jacques \\
\hline & Suffix & \\
\hline & Division & Center for Forest Research (CFR) \\
\hline & Organization & Université du Québec à Montréal \\
\hline & Address & Montréal, QC, H3C 3P8, Canada \\
\hline & Division & $\begin{array}{l}\text { Institut de recherche en biologie végétale, Département de sciences } \\
\text { biologiques }\end{array}$ \\
\hline
\end{tabular}




\begin{tabular}{|c|c|c|}
\hline & Organization & Université de Montréal \\
\hline & Address & 4101 East, Sherbrooke St, Montréal, QC, H1X 2B2, Canada \\
\hline & Email & \\
\hline \multirow[t]{11}{*}{ Author } & Family Name & Fontaine \\
\hline & Particle & \\
\hline & Given Name & Bastien \\
\hline & Suffix & \\
\hline & Division & Center for Forest Research (CFR) \\
\hline & Organization & Université du Québec à Montréal \\
\hline & Address & Montréal, QC, H3C 3P8, Canada \\
\hline & Division & $\begin{array}{l}\text { Institut de recherche en biologie végétale, Département de sciences } \\
\text { biologiques }\end{array}$ \\
\hline & Organization & Université de Montréal \\
\hline & Address & 4101 East, Sherbrooke St, Montréal, QC, H1X 2B2, Canada \\
\hline & Email & \\
\hline \multirow[t]{14}{*}{ Author } & Family Name & Berninger \\
\hline & Particle & \\
\hline & Given Name & Frank \\
\hline & Suffix & \\
\hline & Division & Département des sciences biologiques, CP 8888 Succ, Centre-ville \\
\hline & Organization & Université du Québec à Montréal \\
\hline & Address & Montréal, QC, H3C 3P8, Canada \\
\hline & Division & Center for Forest Research (CFR) \\
\hline & Organization & Université du Québec à Montréal \\
\hline & Address & Montréal, QC, H3C 3P8, Canada \\
\hline & Division & Department of Forest Sciences \\
\hline & Organization & University of Helsinki \\
\hline & Address & PL 27, Helsinki, 00014, Finland \\
\hline & Email & \\
\hline
\end{tabular}

\begin{tabular}{lll}
\hline & Received & \\
\hline \multirow{3}{*}{ Schedule } & Revised & January 2014 \\
& Accepted & 2 August 2014 \\
\hline
\end{tabular}

Abstract

We investigated the effects of leaf color change in the fall on photosynthetic production and nitrogen resorption. Seedlings of Acer platanoides L. and A. saccharum Marsh. were grown in a shade house for 5 months in either $21 \%$ (intermediate light, M) or $4.9 \%$ (low light, L) of incident irradiance. After this period, a subset of the intermediate-light grown seedlings was transferred to a high-light stress treatment $(\mathrm{H})$. Gas exchange, chlorophyll fluorescence, pigments, antioxidant activity, and nitrogen $(\mathrm{N})$ resorption were examined at three leaf senescence stages during September and October. Our results show that plants of both species produce more anthocyanins in the $\mathrm{H}$ treatment. In comparison with plants grown in the $\mathrm{L}$ and $\mathrm{M}$ treatments, plants of both species in the $\mathrm{H}$ treatments had lower chlorophyll, carotenoid and chlorophyll fluorescence parameters $\left(F_{\mathrm{v}} / F_{\mathrm{m}}, \Phi_{\mathrm{PSII}}, \mathrm{NPQ}\right.$ and ETR) at the third sampling date (October 12-18), and indicating higher levels of photoinhibition in the seedlings exposed to high light. Our results imply that autumn leaf redness is inducible and closely linked to photo-oxidative stress. However, anthocyanins did not enhance antioxidant capacity in red leaves in either species, when exposed to high light. For both species, our results showed a higher N-resorption for high-light stressed plants. We also observed that the number of abscised leaves at the second sampling dates (September 10) was higher than at the third sampling dates. The intraleaf distribution of anthocyanin, the association between anthocyanin production and the high-light environments, the retention of red leaves, the substantial physiological gain of photosynthetic activity, as well as the links between anthocyanins and increased $\mathrm{N}$ resorption led us to assume that one primary role of autumn 
anthocyanin could be to protect the photosynthetic apparatus from photo-oxidative damage as light filters rather than as antioxidant. Another major role is to extend carbon capture and help supply the energy needed for $\mathrm{N}$ resorption from senescing leaves in both A. saccharum and A. Platanoides during high-light stress. Nevertheless, photoprotective capacity of anthocyanins was not able to fully compensate for photoinhibitory stress as the anthocyanins are not optimally located to efficiently reduce light within the leaves.

Keywords (separated by '-') Nitrogen resorption - Anthocyanins - Chlorophyll - Photoprotection

Footnote Information Communicated by S. Renault.

Electronic supplementary material The online version of this article (doi:10.1007/s11738-014-1674-x) contains supplementary material, which is available to authorized users. 


\section{Metadata of the article that will be visualized in OnlineAlone}

Electronic supplementary material
Below is the link to the electronic supplementary material. MOESM1: Supplementary material 1 (DOC 43 kb). 


\title{
2 Nitrogen resorption in Acer platanoides and Acer saccharum: 3 influence of light exposure and leaf pigmentation
}

\author{
4 Baoli Duan · Alain Paquette $\cdot$ Philippe Juneau • \\ 5 Jacques Brisson • Bastien Fontaine • \\ 6 Frank Berninger
}

8 (c) Franciszek Górski Institute of Plant Physiology, Polish Academy of Sciences, Kraków 2014

Communicated by S. Renault.

Electronic supplementary material The online version of this article (doi:10.1007/s11738-014-1674-x) contains supplementary material, which is available to authorized users.

\section{B. Duan $\cdot$ P. Juneau $\cdot$ F. Berninger}

Département des sciences biologiques, CP 8888 Succ, Centre-ville, Université du Québec à Montréal, Montréal, QC H3C 3P8, Canada

\section{B. Duan $(\bowtie)$}

Key Laboratory of Mountain Surface Processes and Ecological Regulation, Institute of Mountain Hazards and Environment, Chinese Academy of Sciences, Chengdu 610041, China e-mail: duanbl@imde.ac.cn

\section{A. Paquette - J. Brisson · B. Fontaine - F. Berninger} Center for Forest Research (CFR), Université du Québec à Montréal, Montréal, QC H3C 3P8, Canada

\section{J. Brisson · B. Fontaine}

Institut de recherche en biologie végétale, Département de sciences biologiques, Université de Montréal, 4101 East, Sherbrooke St, Montréal, QC H1X 2B2, Canada

\section{Present Address:}

F. Berninger

Department of Forest Sciences, University of Helsinki, PL 27, 00014 Helsinki, Finland
(N) resorption were examined at three leaf senescence stages during September and October. Our results show that plants of both species produce more anthocyanins in the $\mathrm{H}$ treatment. In comparison with plants grown in the $\mathrm{L}$ and $\mathrm{M}$ treatments, plants of both species in the $\mathrm{H}$ treatments had lower chlorophyll, carotenoid and chlorophyll fluorescence parameters $\left(F_{\mathrm{v}} / F_{\mathrm{m}}, \Phi_{\mathrm{PSII}}, \mathrm{NPQ}\right.$ and ETR $)$ at the third sampling date (October 12-18), and indicating higher levels of photoinhibition in the seedlings exposed to high light. Our results imply that autumn leaf redness is inducible and closely linked to photo-oxidative stress. However, anthocyanins did not enhance antioxidant capacity in red leaves in either species, when exposed to high light. For both species, our results showed a higher N-resorption for high-light stressed plants. We also observed that the number of abscised leaves at the second sampling dates (September 10) was higher than at the third sampling dates. The intra-leaf distribution of anthocyanin, the association between anthocyanin production and the high-light environments, the retention of red leaves, the substantial physiological gain of photosynthetic activity, as well as the links between anthocyanins and increased $\mathrm{N}$ resorption led us to assume that one primary role of autumn anthocyanin could be to protect the photosynthetic apparatus from photo-oxidative damage as light filters rather than as antioxidant. Another major role is to extend carbon capture and help supply the energy needed for $\mathrm{N}$ resorption from senescing leaves in both $A$. saccharum and A. Platanoides during high-light stress. Nevertheless, photoprotective capacity of anthocyanins was not able to fully compensate for photoinhibitory stress as the anthocyanins are not optimally located to efficiently reduce light within the leaves.

Keywords Nitrogen resorption - Anthocyanins .

$\begin{array}{lll}\text { Journal : Large 11738 } & \text { Dispatch : 6-9-2014 } & \text { Pages : 12 } \\ \text { Article No. : } \mathbf{1 6 7 4} & \square \text { LE } & \square \text { TYPESET } \\ \text { MS Code : ACPP-D-14-00009 } & \mho_{\text {CP }} & \checkmark \text { DISK }\end{array}$




\section{Abbreviations}

$A_{\text {sat }} \quad$ Photosynthetic rates at saturating irradiance

Chl Chlorophyll

$\Phi_{\text {PSII }} \quad$ Effective PSII quantum yield

ETR Electron transport rate

$F_{\mathrm{v}} / F_{\mathrm{m}} \quad$ Maximal PSII quantum yield

$\mathrm{IC}_{50} \quad$ Free radical scavenging activity

NPQ Non-photochemical quenching

qP Coefficient of photochemical quenching

\section{Introduction}

While the autumn coloration of tree foliage remains a fascinating spectacle every year, the mechanisms and reasons for temperate and boreal deciduous trees fall coloration are still subject to discussion. At present, there seem to be two main hypotheses, focusing on the role of anthocyanins in photoprotection and on coloration as a signal to herbivores that the tree is not a suitable host (Archetti 2009). It has been reported that some plants up-regulate anthocyanins to protect themselves from photoinhibition by reducing excess excitation energy and avoid oxidative damage (Feild et al. 2001; Hughes et al. 2005). Although there is experimental evidence for a photoprotective role of anthocyanins in many plants, there seems to be cases where anthocyanins do not improve photoprotection (Esteban et al. 2008; Zeliou et al. 2009). The reasons for these conflicting results remain unclear.

Nitrogen $(\mathrm{N})$ remobilization from senescing leaves during the autumn is an important plant nutrient conservation mechanism in temperate deciduous forests and resorption efficiencies in deciduous forests are above $50 \%$ (Vergutz et al. 2012). Changes in irradiance can modify $\mathrm{N}$ resorption, which requires energy (Field 1983) supplied by photosynthesis (Yasumura et al. 2005). However, it seems $\mathrm{N}$ resorption response to different light environments does not show a consistent pattern. Chapin and Moilanen (1991), and May and Killingbeck (1992) found that shading of senescing leaves dramatically reduced resorption efficiency in birches (Betula papyrifera) and oaks (Quercus ilicifolia). By contrast, Yasumura et al. (2005) reported that growth irradiance did not influence $\mathrm{N}$ resorption efficiency in three deciduous woody species (Fagus crenata, Lindera umbellata and Magnolia salicifolia). High irradiances especially, combined with low temperature, are harmful to plant photosynthetic capacity and can ultimately result in photoinhibition and photodamage (Pietrini et al. 2002), which reduces $\mathrm{N}$ resorption (Hoch et al. 2003). The resorption protection hypothesis (Hoch et al. 2003) states that anthocyanins of senescing foliage shield photosynthetic tissues from light stress and enhance nutrient resorption. However, this hypothesis, confirmed in some studies (Hoch et al. 2003; Lee et al. 2003), was rejected in other studies (Feild et al. 2001). The resorption protection role of anthocyanins, therefore, requires further investigation.

Lev-Yadun and Holopainen (2009) discussed that while yellow autumn colors prevail in Europe, reds seem to be more important in Eastern Asia and North America. They argued that the reason for their difference in autumn colors could be a product of adaptation to past climates and herbivore faunas. Acer platanoides L. (Norway maple), is a Eurasian tree species that was introduced in North America, while A. saccharum Marsh. (Sugar maple) is a widespread native. A. saccharum usually has a flaming orange autumn color while the color of A. Platanoides is normally yellow. In this study, we characterized the relationship between anthocyanins, leaf senescence, photosynthesis and nutrient resorption during autumn for A. Platanoides and A. saccharum. During the experiment, trees were exposed to different light levels to induce photoinhibitory stress. Specifically, we hypothesized that nitrogen resorption is less efficient in stressed plants (high light $<$ low light $<$ intermediate light).

\section{Materials and methods}

Experimental design and treatments

The experiment was conducted at the Montreal Botanical Garden, Quebec, Canada $\left(45^{\circ} 33.7^{\prime} \mathrm{N}, 073^{\circ} 34.3^{\prime} \mathrm{W}\right)$. Results from the same experimental setup on the competitive performance of the two species are reported in Paquette et al. (2012) identifying species' characteristics that would indicate invasiveness. Acer Platanoides (Norway maple) and A. saccharum (sugar maple) seedlings were raised from seeds collected from mature trees in Montreal for the former, and from the Québec provincial forest nursery for the latter. Seeds were stratified and then sown in humid sand boxes filled with layers of sand and minced leaf litter. Germinated seeds were transferred to $320-\mathrm{mL}$ multi-cell containers and placed at random in their respective light regime for 2 months, at which time they were transferred to larger $6.7 \mathrm{~L}$ pots. Germinated seedlings were raised in dynamic shade houses under two light levels: $21 \%$ (intermediate light, $\mathrm{M}$ treatment) and $4.9 \%$ (low light, L treatment) of full incident photosynthetic photon flux density (PPFD) (measured on September 9, 2009), mimicking conditions found under forest gaps and closed forest understories, respectively, (see Paquette et al. 2012 for experimental setup and light measurement details). These light levels were obtained by varying the size of roof openings and calibrated using whole-day PPFD

\begin{tabular}{|l|ll|}
\hline Journal : Large 11738 & Dispatch : 6-9-2014 & Pages : 12 \\
Article No. : $\mathbf{1 6 7 4}$ & $\square$ LE & $\square$ TYPESET \\
MS Code : ACPP-D-14-00009 & $\checkmark$ CP & $\checkmark$ DISK \\
\hline
\end{tabular}


measurements. In a previous experiment, Paquette et al. (2010) demonstrated the inadequacy of homogenous shadecloth greenhouses for mimicking forest understories. Maximum incident irradiance during a sunny day in September is around $1,600 \mu \mathrm{mol} \mathrm{m}{ }^{-2} \mathrm{~s}^{-1}$ in Montreal. All seedlings were arranged into four replicated blocks, each comprising the two light treatments assigned at random, and the two species. Thus, each block is then a replicate of the light treatment.

All seedlings were well watered throughout the experiment and fertilized using $15 \mathrm{~g}$ Nutricote 20-7-10 type 180 per pot. On August 25, 2009 (5 months after leaf emergence), we took a total of 48 seedlings from the larger experiment and assigned them to the present study on leaf redness. Two seedlings per species and per original light treatment ( $\mathrm{M}$ and $\mathrm{L}$ ) were chosen from each of the blocks to be part of the present study. These 32 seedlings remained in their original location for the present experiment. To make our high-light treatment $(\mathrm{H})$, an additional 16 seedlings, 8 per species (two from each block), were taken and moved out from the $\mathrm{M}$ treatment $(21 \%$ of incident PPFD) and placed about a meter away from the eastern walls of their respective shadehouse block, under high-light conditions ( $\sim 86 \%$ of full sunlight) but still protected against dominant winds. We compared trait means for plants that remained in the low- and intermediate-light treatment with those switched from the intermediate light to the high-light treatment to determine whether high-light stress induce anthocyanin. The experiment was a factorial design of two species and three light environments. There were eight seedlings per species and per light treatment, which were spatially arranged into four replication blocks (two seedlings per treatment in each block). Measurements of gas exchange, chlorophyll fluorescence imaging, pigments, antioxidant activity, and nitrogen resorption were performed at three different sampling dates from the end of August to the end of September. At the time of the first sampling period (August 25-September 5), both species maintained their green colors across all light treatments. At the second sampling period (September 10October 3), A. Platanoides and A. saccharum still could be seen as greenish for all the three light treatments, despite leaves of both species starting to turn color in high-light treatment. At third sampling dates (October12-18), leaves of the A. Platanoides and A. saccharum had turned already to their respective fall colors.

\section{Pigment determination}

For each species and treatment, leaves of four to six plants from three blocks were collected at each leaf sampling dates for the determination of pigment concentrations. Leaf discs were sampled on all trees and were immediately frozen on dry ice in the field, and subsequently stored at $80{ }^{\circ} \mathrm{C}$ until analysis. Frozen discs were ground in $100 \%$ acetone with a small amount of quartz sand in a chilled mortar. Chlorophylls (Chl) were determined using a multiwavelength analysis at 470, 645, 662 and $710 \mathrm{~nm}$ (Lichtenthaler and Buschmann 2001) with a CARY 300 UV-Visible spectrophotometer. For anthocyanin determination, leaf discs were disrupted in liquid nitrogen and extracted in $1.25 \mathrm{~mL}$ of $3 \mathrm{M} \mathrm{HCl}: \mathrm{H}_{2} \mathrm{O}: \mathrm{MeOH}$ (1:3:16 by vol.) using a tissue homogenizer. The concentration of anthocyanins was estimated spectrometrically according to Murray and Hackett (1991).

Gas exchange measurements

Photosynthetic rates $\left(A_{\text {sat }}\right)$ were determined on September 3 and 4, September 29, and October 15, 2009 with a portable photosynthesis system (GFS-3000, Walz, Effeltrich, Germany) at saturating photon flux density $\left(1,400 \mu \mathrm{mol} \mathrm{m}{ }^{-2} \mathrm{~s}^{-1}\right)$ and ambient $\mathrm{CO}_{2}$ concentration (400 ppm). Leaf temperatures (mean \pm SD) were $25.0 \pm 2.9$ on September 3 and $4,15.2 \pm 0.1$ on September 29 , and $10.4 \pm 0.8{ }^{\circ} \mathrm{C}$ on October 15 , respectively.

\section{Chlorophyll fluorescence measurements}

Fluorescence measurements were carried out with an IMAGING-PAM chlorophyll fluorometer (Heinz Walz $\mathrm{GmbH}$, Effeltrich, Germany). The instrument uses blue LEDs for measuring actinic and saturation pulse light. Leaves were dark adapted for at least 30 min prior to the measurements to completely reoxidize PSII electron transporters. Fluorescence was measured with relatively weak light pulses $\left(<1 \mu \mathrm{mol} \mathrm{m} \mathrm{m}^{-2} \mathrm{~s}^{-1}\right)$ at a low frequency $(1 \mathrm{~Hz})$ for measurement of minimal fluorescence $\left(F_{\mathrm{o}}\right)$. Maximal fluorescence yield of a dark-adapted leaf $\left(F_{\mathrm{m}}\right)$ was measured during an 800-ms exposure to a photon flux of approximately $2,600 \mu \mathrm{mol} \mathrm{m} \mathrm{m}^{-2} \mathrm{~s}^{-1}$. Leaves were then illuminated for $9 \mathrm{~min}$ with actinic light $\left(400 \mu \mathrm{mol} \mathrm{m} \mathrm{m}^{-2}\right.$ $\mathrm{s}^{-1}$ ) to induce electron transport, and saturating pulses were applied to determine maximum fluorescence of lightadapted leaves $\left(F_{\mathrm{m}}^{\prime}\right)$. When performing a measurement, an area of interest (AOI) with a diameter of $1 \mathrm{~cm}$ was selected in the center of the leaf. Maximal PSII quantum yield $\left(F_{\mathrm{v}} /\right.$ $F_{\mathrm{m}}$, equivalent to $\left.\left(F_{\mathrm{m}}-F_{\mathrm{o}}\right) / F_{\mathrm{m}}\right)$, effective PSII quantum yield $\left(\Phi_{\mathrm{PSII}}\right)$, non-photochemical quenching $(\mathrm{NPQ})$ and coefficient of photochemical quenching (qP) were averaged over the AOI. Estimates of $\Phi_{\mathrm{PSII}}, \mathrm{qP}$, and NPQ were calculated for each irradiance step using the equations of Genty et al. (1989) and Maxwell and Johnson (2000). Rapid light curve measurements were carried out using 30 -s exposures to stepwise increased PPFD $(1,24,54,103$, $265,532,599,831,1,029,1,322,1,617,2,001$, and 
2,603 $\mu \mathrm{mol} \mathrm{m}{ }^{-2} \mathrm{~s}^{-1}$ ). Simultaneously, apparent electron transport rate (ETR) values were estimated as $\mathrm{ETR}=\Phi_{\mathrm{PSII}} \times 0.5 \times A \times$ incident PPFD, where 0.5 is a factor that assumes equal distribution of energy between the two photosystems (Björkman and Demmig 1987), $A$ is the computed sample absorbance and PPFD is the actinic light intensity.

\section{Antioxidant activity assay}

Antioxidant activity of leaf extracts was assessed by determining their ability to scavenge 1,1-diphenyl-2-picryl hydrazyl (DPPH), a stable free radical. Leaf discs were sampled at each sampling dates as above. Extractions were conducted at $4{ }^{\circ} \mathrm{C}$ in the dark with acetic acid: water: methanol $(7: 23: 70, \mathrm{v} / \mathrm{v} / \mathrm{v})$. Reaction mixtures containing $0-100 \mu \mathrm{L}$ leaf extract and $1.5 \mathrm{~mL}$ of $18 \mu \mathrm{M}$ DPPH in $\mathrm{MeOH}$ were diluted with $\mathrm{MeOH}$ to a final volume of $1.6 \mathrm{~mL}$, vortexed, and then held at room temperature for $30 \mathrm{~min}$, after which the absorbance of the mixtures at $517 \mathrm{~nm}$ was measured. Antioxidant activity of the leaf extracts was expressed as an effective concentration for radical scavenging $\left(\mathrm{IC}_{50}\right)$ : the concentration of fresh leaf material $\left(\mathrm{mg} \mathrm{mL}^{-1}\right)$ required to produce a $50 \%$ reduction in $\mathrm{A}_{517}$ relative to the control mixture to which only methanol was added (van den Berg and Perkins 2007).

Leaf nitrogen analysis and leaf nitrogen in cell walls

To examine foliar nitrogen $(\mathrm{N})$ resorption patterns, we collected fully expanded young to medium-aged green leaves of four to six different individuals of each species. Red leaves that were still attached to branches just before defoliation were sampled when some leaves were fully senescent, falling readily at a touch. Also, shed leaves were counted at intervals of 6 days. Leaf samples were ground and passed through a 20 mesh screen after being first dried at $70{ }^{\circ} \mathrm{C}$ for $36 \mathrm{~h}$. The total concentrations of $\mathrm{N}$ were determined by the semi-micro Kjeldahl method (Mitchell 1998). For each treatment, $N$ resorption efficiency was calculated as $\left(N_{\mathrm{g}}-N_{\mathrm{s}}\right) / N_{\mathrm{s}} \times 100 \%$ in which $N_{\mathrm{g}}$ is the green leaf $\mathrm{N}$ concentration and $N_{\mathrm{s}}$ is the senescent leaf $\mathrm{N}$ concentration (Sanz-Pérez et al. 2009).

Leaf proteins can be divided into water-soluble, SDSsoluble, and SDS-insoluble fractions. The contents of water-soluble, SDS-soluble, and SDS-insoluble fractions were determined as described by Takashima et al. (2004). About $0.3 \mathrm{~g}$ frozen leaf disc was powdered in liquid nitrogen in a mortar with a pestle and homogenized in $1 \mathrm{~mL}$ of $100 \mathrm{mM}$ Na-phosphate buffer ( $\mathrm{pH} 7.5$ ) system with $0.4 \mathrm{M}$ sorbitol, $2 \mathrm{mM} \mathrm{MgCl} 2,10 \mathrm{mM} \mathrm{NaCl}, 5 \mathrm{mM}$ iodoacetate, $1 \%$ (v/v) polyvinylpyrroridone (PVP), $5 \mathrm{mM}$ phenylmethylsulfonyl fluoride (PMSF), and $5 \mathrm{mM}$ dithiothreitol (DTT), after water-soluble, SDS-soluble, and SDSinsoluble fractions were isolated, the protein content were determined by the method of McGrath (1972). The detergent-insoluble fraction is the protein in cell walls. The ratio of cell wall proteins to total leaf proteins was also calculated. $N$ content in cell walls was calculated from cell wall proteins with a conversion coefficient $\left(0.16 \mathrm{~g} \mathrm{~N} \mathrm{~g}^{-1}\right.$ wall proteins) (Feng et al. 2009). The proportion of leaf $\mathrm{N}$ allocated to cell walls was calculated as $\mathrm{N}$ content in cell walls/total leaf $\mathrm{N}$.

Statistical analysis

The experiment consisted of a factorial design of two species, three light levels. There were eight seedlings per species and per light treatment, which were spatially arranged into four replication blocks (two seedlings per treatment in each block). The average of the seedlings within a replicate block was used as the value of a true replicate in the analysis. To meet the requirement of normal distribution, $\mathrm{N}$ concentration were log-transformed before analyses. We performed three-way ANOVA for the effects of light, sampling date and species for each variable to discover differences between species in response to light and sampling date. When analyses revealed sampling date and species interactions, or light and species interactions, or light and sampling date and species interactions for certain variables, two-way ANOVAs for light and sampling date were conducted for each species. Significant differences among treatment means were analyzed using Tukey's multiple comparison post hoc tests. In addition, the effects of light, species and their interactions for $\mathrm{N}$ resorption were determined using two-way analysis of variance (ANOVA). Simple linear regression was used to determine the relationships between $\mathrm{N}$ resorption and anthocyanin levels in leaves. All statistical analyses were conducted in SPSS (SPSS 11.5 for windows, SPSS Inc., Chicago, IL, USA). $P$ values lower than $5 \%$ were considered as statistically significant.

\section{Results}

Effects of light on pigment contents

Compared to intermediate light (M) and low light (L), high-light treatment $(\mathrm{H})$ significantly decreased $\mathrm{Chl}$ concentrations (by 38-91\%) in A. Platanoides at the second and the third sampling dates (Fig. 1a), and increased anthocyanin concentrations (by 53-95\%) across the three sampling dates (Fig. 1b). For A. saccharum, high light-
340

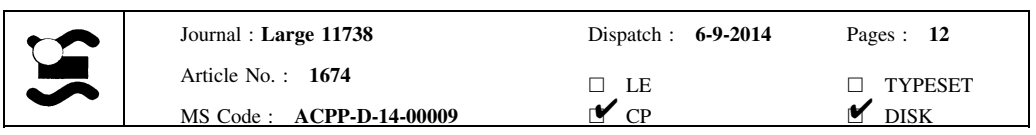



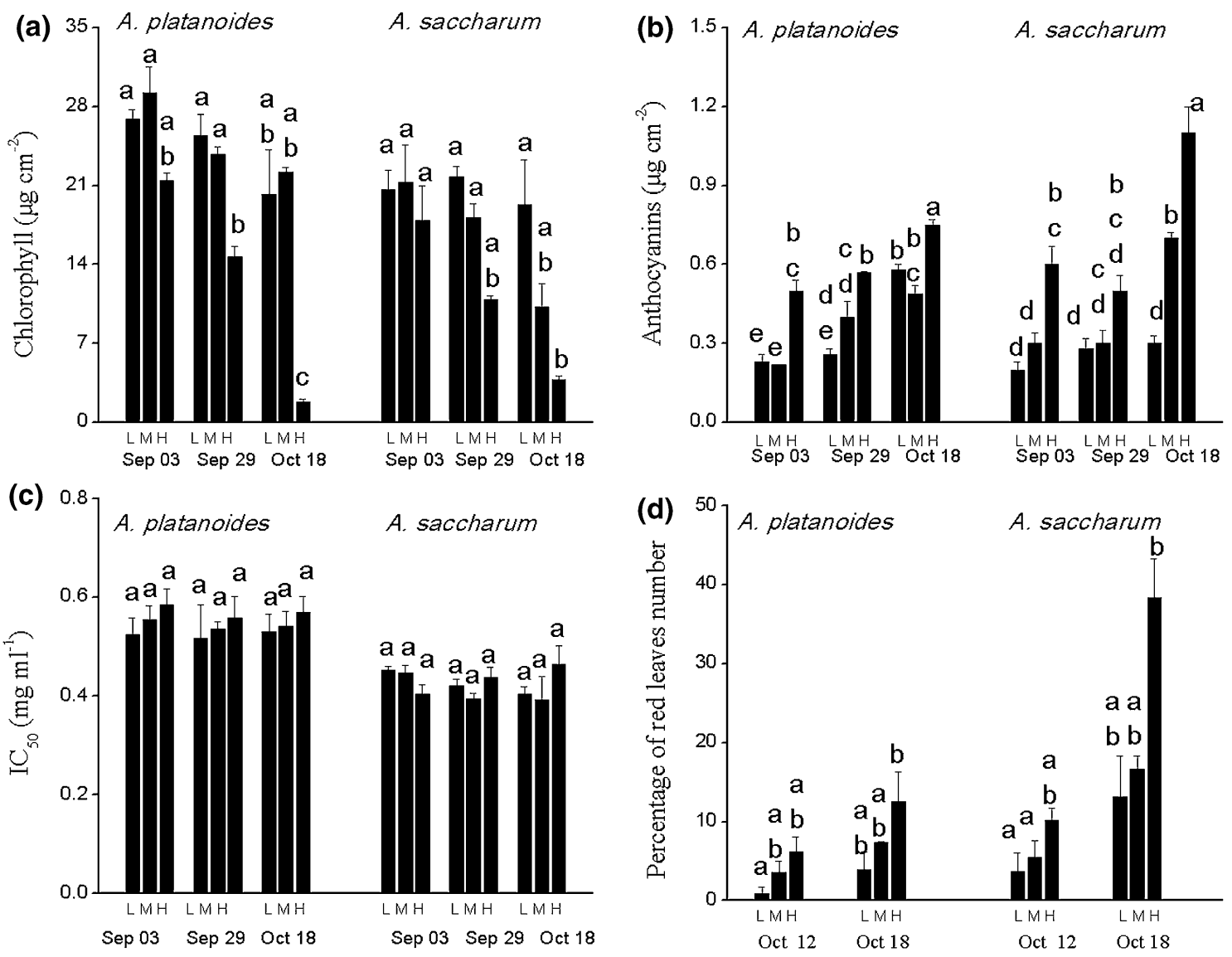

Fig. 1 Effects of light on chlorophyll (Chl) and anthocyanin concentrations, free radical scavenging activity $\left(\mathrm{IC}_{50}\right)$ and number of red leaves in A. platanoides and A. saccharum. Treatments: M, intermediate light ( $21 \%$ of full light); L, low light ( $4.9 \%$ of full light); $\mathrm{H}$, plants from intermediate light switched to the high-light

induced significant reductions in $\mathrm{Chl}$ concentrations compared with the $\mathrm{L}$ and $\mathrm{M}$ treatment at the second and the third sampling period. Meanwhile, in comparison with both the $\mathrm{L}$ and $\mathrm{M}$ treatment, there was significant increase of the anthocyanin concentrations at the first and the third sampling dates in A. saccharum (Fig. 1b). There were significant date $\times$ light interactions in chlorophyll, and the proportion of red leaves (see Supplementary Appendix 1), indicating that high-light stress had a more pronounced effect on these parameters during the third sampling period. Further, there were significant date $\times$ light $\times$ species interactions on anthocyanins. This interaction suggests that high light was associated with significantly higher anthocyanins in A. saccharum during the third measurement period. However, neither light nor sampling dates significantly affected $\mathrm{IC}_{50}$ (Fig. 1c). In addition, the percentage of red leaves numbers also increased faster in A. saccharum than in A. Platanoides, as indicated by the date $\times$ species interaction (see Supplementary Appendix 1, Fig. 1d). environment. Fore each species, the values not sharing the same letters are significantly different $(p<0.05)$ according to Tukey's test. Each value is the mean of three replicates, consisting of 4-6 seedlings of each species and treatment, error bars are SE. Figure 1d, measured at two census dates $(10 / 12,10 / 31)$ in the 2009 growing season

Effects of light on photosynthetic rates and chlorophyll fluorescence parameters

Compared to both the $\mathrm{L}$ and $\mathrm{M}$ treatment, the $\mathrm{H}$ treatment 368 significantly reduced $A_{\text {sat }}$ by $62-71 \%$ in A. Platanoides and $36-75 \%$ in $A$. saccharum at the first and second sampling dates (Fig. 2a). For both species, at the second and the third sampling dates, $F_{\mathrm{v}} / F_{\mathrm{m}}$ was lower in seedlings grown under $\mathrm{H}$ treatment compared with seedlings under $\mathrm{L}$ and $\mathrm{M}$ treatments (Fig. 2b). The changing tendency of ETR was compatible with that of $\Phi_{\text {PSII }}$ (Fig. 2c, e). At the third sampling dates, $\Phi_{\text {PSII }}$ decreased at high-light stress for both species (Fig. 2e). Compared to $\mathrm{M}$ treatment, the dynamic changes in $\Phi_{\mathrm{PSII}}$ and NPQ in A. Platanoides under $\mathrm{H}$ treatment with photooxidation seem to involve three stages of alteration: at the first sampling stage, both $\Phi_{\text {PSII }}$ and NPQ decreased; at the second stage, $\Phi_{\text {PSII }}$ slightly decreased and NPQ increased; and at the third leaf sampling stage, both parameters decreased. ETR increases with the intensity of the actinic light during the rapid light

\begin{tabular}{|l|lll|}
\hline Journal : Large $\mathbf{1 1 7 3 8}$ & Dispatch : 6-9-2014 & Pages : $\mathbf{1 2}$ \\
Article No. : $\mathbf{1 6 7 4}$ & $\square$ LE & $\square$ TYPESET \\
MS Code : ACPP-D-14-00009 & $\sim_{\text {CP }}$ & $\checkmark$ DISK \\
\hline
\end{tabular}


Fig. 2 Effects of light on net photosynthesis rate $(A)$, maximal PSII quantum yield $\left(F_{\mathrm{v}} / F_{\mathrm{m}}\right)$, electron transport rate (ETR), coefficient of photochemical quenching (qP), effective PSII quantum yield $\left(\Phi_{\mathrm{PSII}}\right)$, and non-photochemical quenching (NPQ) at $1,400 \mu \mathrm{mol} \mathrm{m}{ }^{-2} \mathrm{~s}^{-1}$ PPF in $A$. platanoides and A. saccharum. Treatments: $\mathrm{M}$, intermediate light ( $21 \%$ of full light); L, low light ( $4.9 \%$ of full light); $\mathrm{H}$, plants from intermediate light switched to the high-light environment. Fore each species, the values not sharing the same letters are significantly different $(p<0.05)$ according to Tukey's test. Each value is the mean of two replicates, consisting of four seedlings of each species and treatment, error bars are SE
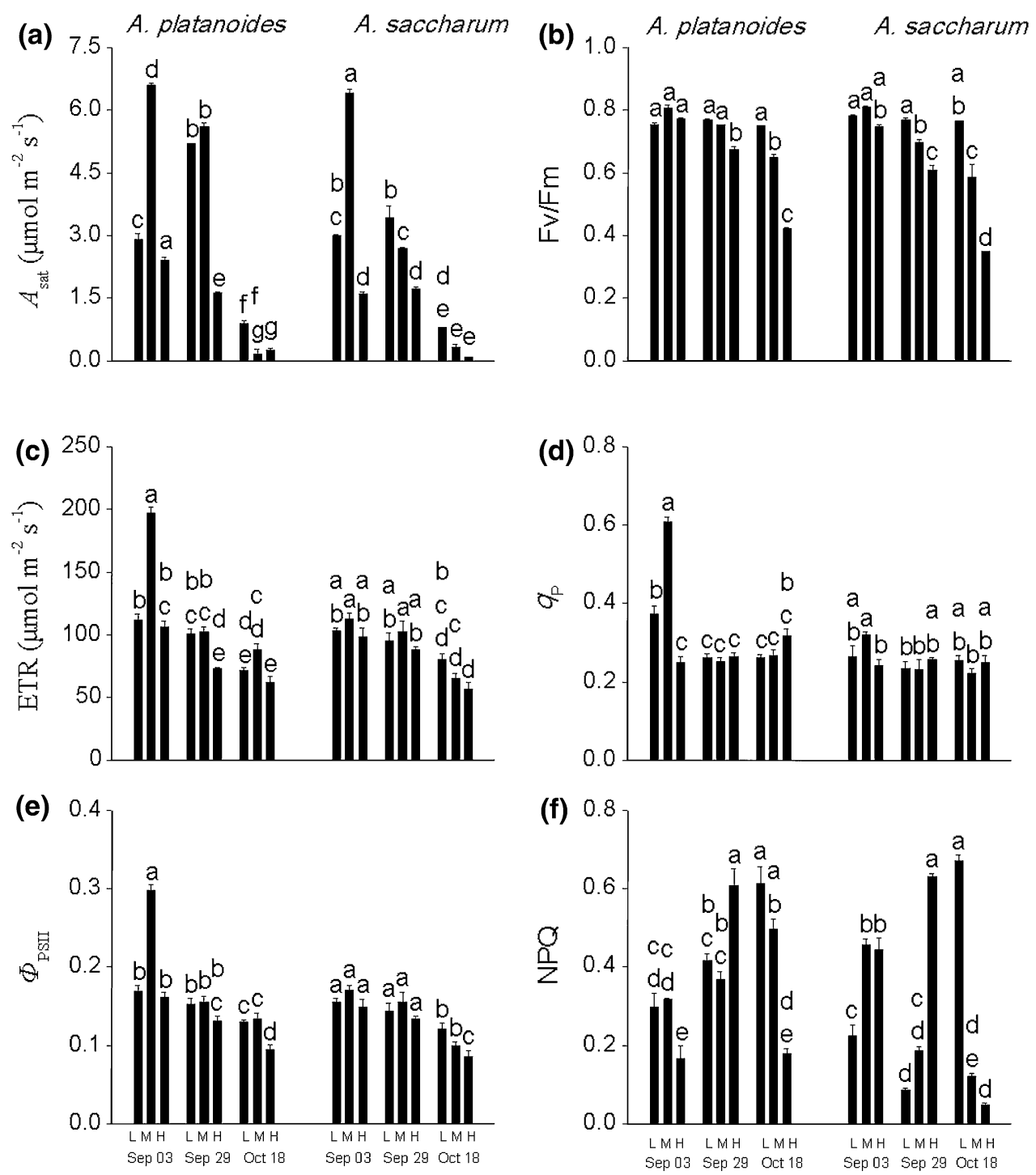

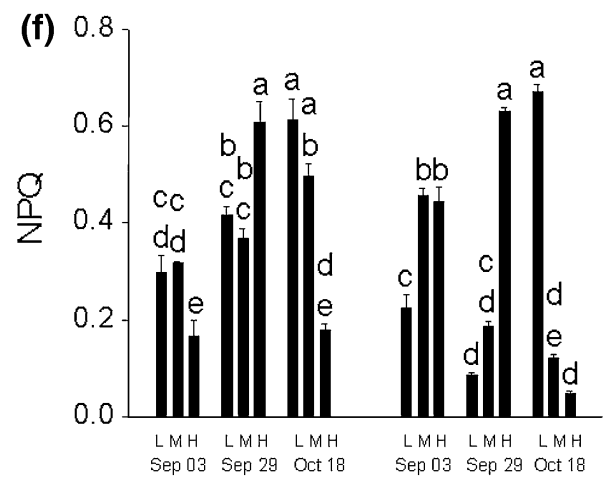

385 curves. It is lower (in some cases) in leaves of the $\mathrm{H}$ 38 AQ1 treatment (Fig. 3). For both species, a125bove $387500 \mu \mathrm{mol} \mathrm{m}{ }^{-2} \mathrm{~s}^{-1}$ PPFD, light-dependent ETR in plants 388 under high-light conditions at the third sampling dates was 389 lowest. Across all light treatments, ETR was higher under 390 L and $\mathrm{M}$ treatments than under $\mathrm{H}$ treatment.

391 Effects of light on leaf $\mathrm{N}$ and $\mathrm{N}$ resorption efficiency

392 There was a tendency for A. Platanoides seedlings 393 exposed to high light to have lower leaf $\mathrm{N}$ relative to low 394 light and intermediate light at the third sampling dates. 395 For $A$. saccharum, the $\mathrm{H}$ treatment significantly decreased 396 leaf $\mathrm{N}$ at the second sampling date relative to $\mathrm{M}$ treat397 ment, and at the third sampling date relative to $\mathrm{L}$ treat398 ment (Fig. 4a). N concentration in cell wall, fraction of 399 leaf $\mathrm{N}$ in cell wall and $\mathrm{N}$ resorption were similar in seedlings under $\mathrm{L}$ and $\mathrm{M}$ treatments (Fig. 4b-d). For both species, the fraction of leaf $\mathrm{N}$ in cell wall of seedlings exposed to the high light increased significantly relative to seedlings under $\mathrm{M}$ treatment at the third sampling date (Fig. 4c). Furthermore, the leaf $\mathrm{N}$ concentration in cell wall and the fraction of leaf $\mathrm{N}$ in cell wall also increased more rapidly in A. saccharum than in A. Platanoides, as indicated by the date $\times$ species interaction (see Supplementary Appendix 1, Fig. 4). N resorption of seedlings under $\mathrm{H}$ treatment increased by 42 and $36 \%$ in comparison with seedlings under $\mathrm{M}$ treatments in A. Platanoides and $A$. saccharum, respectively (Fig. 4d). The two species differed in the amount of $\mathrm{N}$ resorption only at low light. In addition, there were positive relationships between $\mathrm{N}$ resorption and the anthocyanin content of leaves in $A$. saccharum $\left(r^{2}=0.49, P=0.04\right.$ for all treatment data pooled together) (Fig. 5).
400

401

402

403

404

405

406

407

408

409

410

411

412

413

414

415

416

\begin{tabular}{|l|lll|}
\hline Journal : Large $\mathbf{1 1 7 3 8}$ & Dispatch : 6-9-2014 & Pages : $\mathbf{1 2}$ \\
Article No. : $\mathbf{1 6 7 4}$ & $\square$ LE & $\square$ TYPESET \\
MS Code : ACPP-D-14-00009 & $\sim_{\text {CP }}$ & $\checkmark$ DISK \\
\hline
\end{tabular}


Fig. 3 Effects of light on the electron transport rate (ETR)light response curves in $A$. platanoides and A. saccharum at the first sampling dates (September 3, a, b), the second sampling dates (September 29, c, d), and the third sampling dates (October18, e, f). Exposures (30 s) to stepwise increased photon irradiance $(1$, $24,54,103,265,532,599,831$, $1,029,1,322,1,617,2,001$, and $2,603 \mu \mathrm{mol} \mathrm{m}^{-2} \mathrm{~s}^{-1}$ ) were provided. Each value is the mean of two replicates, consisting of four seedlings of each species and treatment, error bars are SE. Treatments: $\mathrm{M}$, intermediate light ( $21 \%$ of full light); L, low light (4.9\% of full light); $\mathrm{H}$, plants from intermediate light switched to the high-light environment
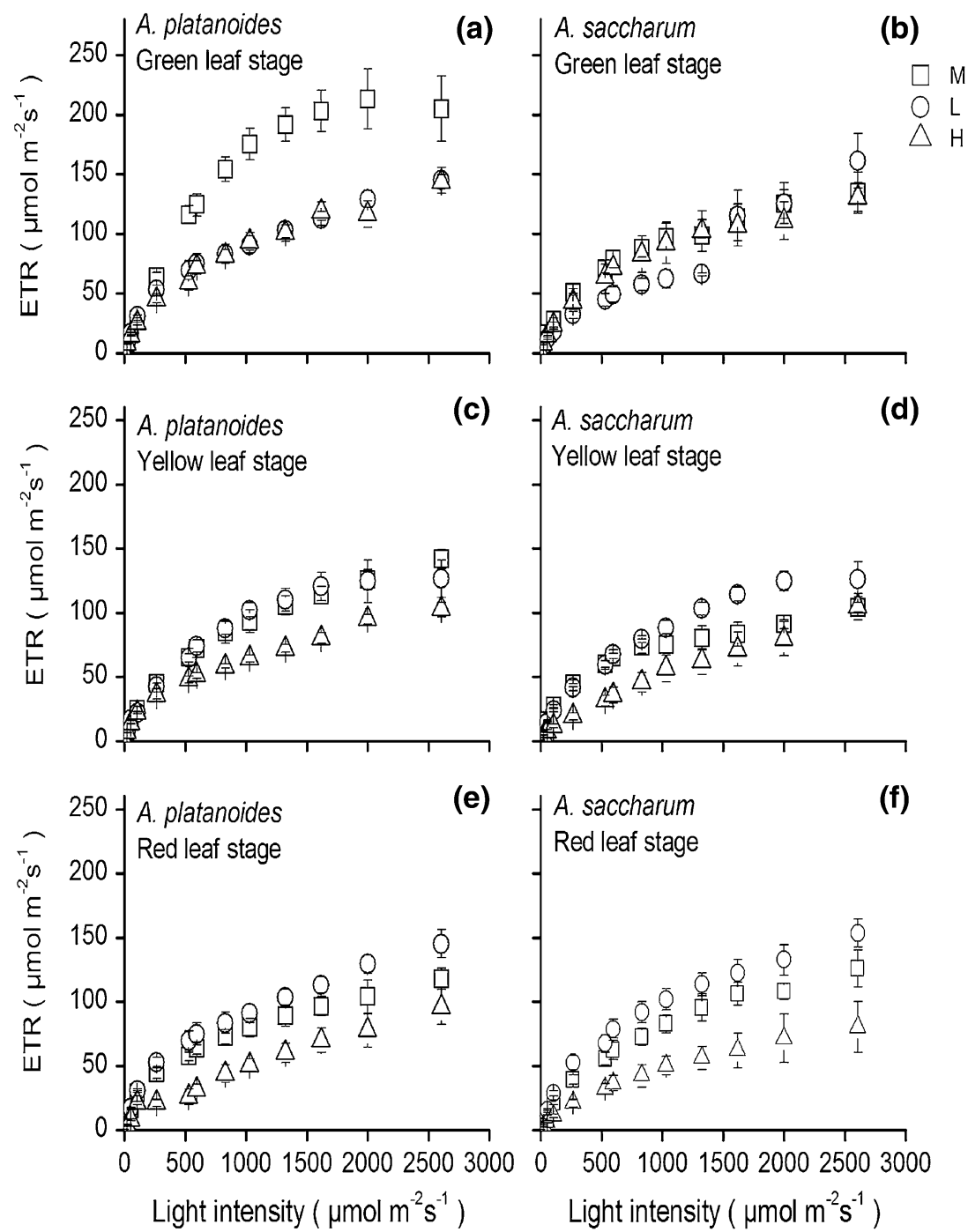

\section{Effects of light on number of leaves shedding}

In both species, the accumulated proportions of leaves shed in late September and October differed among treatments. For both species in all treatments, leaf shed sharply at second sampling dates (September 10-October 3) (Fig. 6). In contrast, at the third sampling dates (October 12-18), both species shed few additional leaves. In addition, L treatment had a lower leaf abscission rate at the second sampling stage, compared with $\mathrm{H}$ treatment (Fig. 6).

\section{Discussion}

As expected, significant increases in anthocyanin concentrations and reductions in chlorophyll concentrations, net photosynthetic rate, maximal PSII quantum yield $\left(F_{\mathrm{v}} /\right.$ $\left.F_{\mathrm{m}}\right)$, effective PSII quantum yield $\left(\Phi_{\mathrm{PSII}}\right)$ were observed in high-light stressed plants relative to plants grown in intermediate light and in low light. Moreover, the $\mathrm{N}$ content in the high-light stressed leaves of A. saccharum was also lower. These lower $\mathrm{N}$ contents could be the reason for the lower photosynthetic rates in the high-light plants (Zeliou et al. 2009), as the majority of leaf $\mathrm{N}$ is associated with the photosynthetic function of the leaf (Feng et al. 2009). We also observed that resorption of $\mathrm{N}$ was more efficient under light stress. This is contrary to our initial hypothesis that photoinhibition would reduce leaf $\mathrm{N}$ re-translocation. On the other hand, during the third measurement period, high light was associated with significantly higher anthocyanin concentrations in A. saccharum compared to A. Platanoides, indicated by the significant interaction between light, species and sampling dates on anthocyanin concentrations. Nevertheless, our results fail to explain how the high-light stressed leaves of A. Platanoides, with lower anthocyanin concentrations, are as efficient in translocating $\mathrm{N}$ as A. saccharum. It is

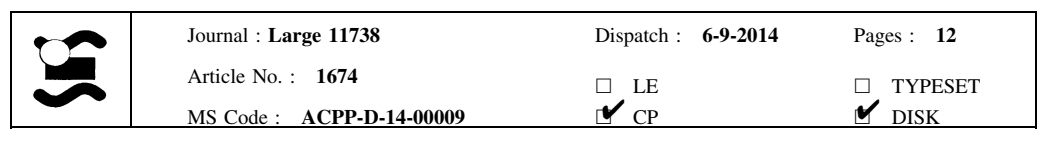



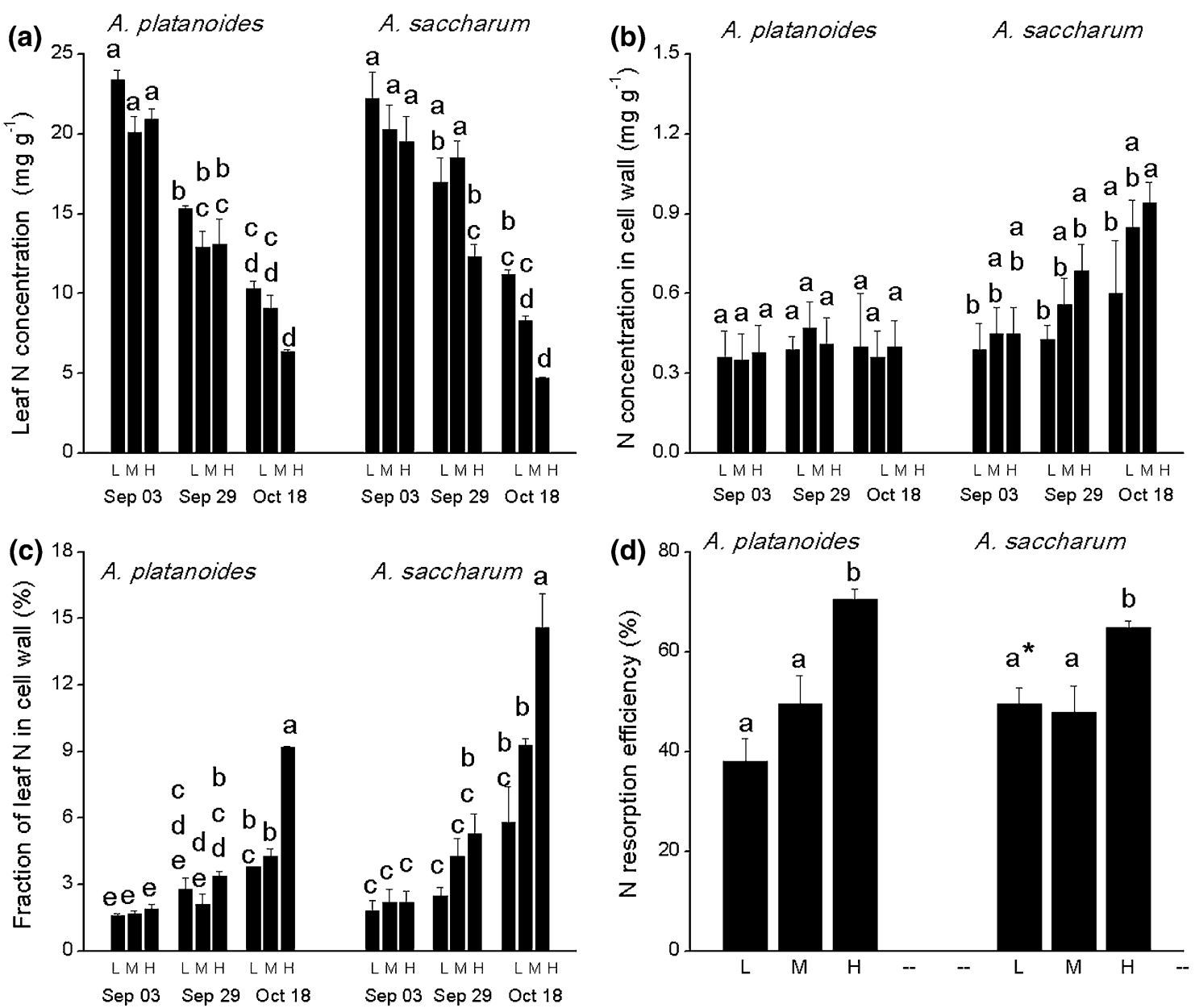

Fig. 4 Effects of light on leaf nitrogen content, nitrogen resorption in A. platanoides and A. saccharum. Treatments: $\mathrm{M}$, intermediate light (21\% of full light); L, low light (4.9\% of full light); H, plants from intermediate light switched to the high-light environment. For each species, values not sharing the same letters are significantly different

$(p<0.05)$ according to Tukey's test. In addition, for $\mathrm{N}$ resorption values, the asterisks indicate statistically significant differences between the two species within the same light treatment. Each value is the mean of three replicates, consisting of 4-6 seedlings of each species and treatment, error bars are SE

possible that the weaker production of anthocyanins by $A$. Platanoides during autumn senescence is compensated by alternative radical scavenging capacity (van den Berg and Perkins 2007). Anthocyanins are not obligatory for physiological protection, as illustrated by the many temperate trees functioning successfully with yellow autumn leaves (Lev-Yadun and Holopainen 2009).

In our study, the occurrence of leaf redness was coupled to the light environment (Fig. 1b, d), with the reddest leaves (higher anthocyanin concentrations) occurring in the sunniest treatments (Kozlowski and Pallardy 1997). Chlorophyll levels differed considerably between both treatments and senescing developmental stage. These observations indicate that autumnal anthocyanins accumulate and the simultaneous chlorophyll loss is correlated to photoinhibitory environments (Zeliou et al. 2009). A decrease in dark-adapted $F_{\mathrm{v}} / F_{\mathrm{m}}$ is generally used as a measure of photoinhibition (Björkman and Demmig 1987;
Perron and Juneau 2011). During the second and third sampling dates, the rapid decrease in $F_{\mathrm{v}} / F_{\mathrm{m}}$ of plants under high-light conditions compared to plants under intermediate-light conditions also indicates onset of photodamage to PSII. Non-photochemical quenching (NPQ) rose between the first and the second sampling period, indicating increased excess energy dissipation (Lepeduš et al. 2011), but declined during third sampling date, possibly due to oxidative damage in thylakoid membranes and lower rates of linear electron transport (Gielen et al. 2007). We would expect lower ETR in red leaves than green leaves when exposed to the same incident light intensity as the actual light intensity reaching the chloroplasts of a red leaf is lower due to absorption by anthocyanins (Zeliou et al. 2009). This was the case in our study as we observed that ETR at the third sampling periods when leaves turned red was lowest with respect to other sampling dates. The reduction of the $\Phi_{\mathrm{PSII}}$, NPQ and ETR explained the

\begin{tabular}{|l|lll|}
\hline & Journal : Large 11738 & Dispatch : 6-9-2014 & Pages : $\mathbf{1 2}$ \\
Article No. : $\mathbf{1 6 7 4}$ & $\square_{\mathrm{CP}}^{\mathrm{LE}}$ & $\square_{\text {TISK }}^{\text {TYPESET }}$ \\
\hline
\end{tabular}




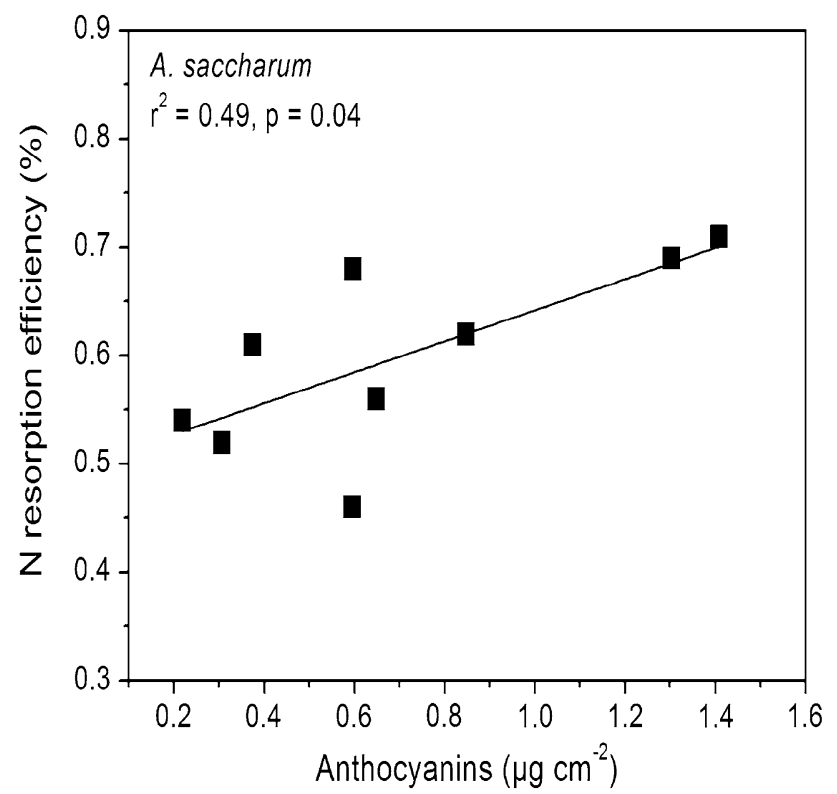

Fig. 5 Relationships between the $\mathrm{N}$ resorption and the anthocyanin content of leaves in A. saccharum $\left(r^{2}=0.49, P=0.04\right.$ for all treatment data pooled together). The values are shown for individual replicates

486

487

488

489

490

491

492

493

494

495

496

497

498

499

500

501

502

503

504

505

506

507

508

509

510 reduction in the $\mathrm{CO}_{2}$ fixation as suggested by $\mathrm{Lu}$ and Zhang (1998). We found that exposure to high light speeds up the senescence process, as suggested by the decreased $F_{\mathrm{v}} / F_{\mathrm{m}}$ (Fig. 2b) and the increased accumulation of anthocyanins. This further indicates that autumn leaf redness is inducible and closely linked to photo-oxidative stress, and points to a higher need for the buildup of a photoprotection system. During the third measurement period, $\mathrm{CO}_{2}$ assimilation was low, while ETR was at reasonably high values, especially in A. saccharum. It maybe that high-light stress during leaf senescence stimulates the partitioning of electron flow to pathways other than $\mathrm{CO}_{2}$ assimilation (Park et al. 1996). These findings suggest that photosynthesis under high-light conditions is limited by the electron utilization capacity, not by the electron transport capacity (Fujiki et al. 2007). This could be due to the low leaf internal conductance in red leaves (Miyazawa and Yahata 2006). Lower leaf internal conductance leads to lower $\mathrm{CO}_{2}$ concentration at the site of RuBP carboxylation and oxygenation, which results in more electrons being used for RuBP oxygenation (Miyazawa and Yahata 2006), and hence low $\mathrm{CO}_{2}$ assimilation while still relatively high ETR. Additionally, we observed the leaves of A. saccharum exhibited slower leaf senescence under high light than did A. Platanoides, as shown by smaller decreases in chlorophyll, $\Phi_{\mathrm{PSII}}$, and ETR which might be due to A. saccharum seedlings having bigger amounts of anthocyanins.

The role of anthocyanin as antioxidants or as light screens should depend on their localization within plant
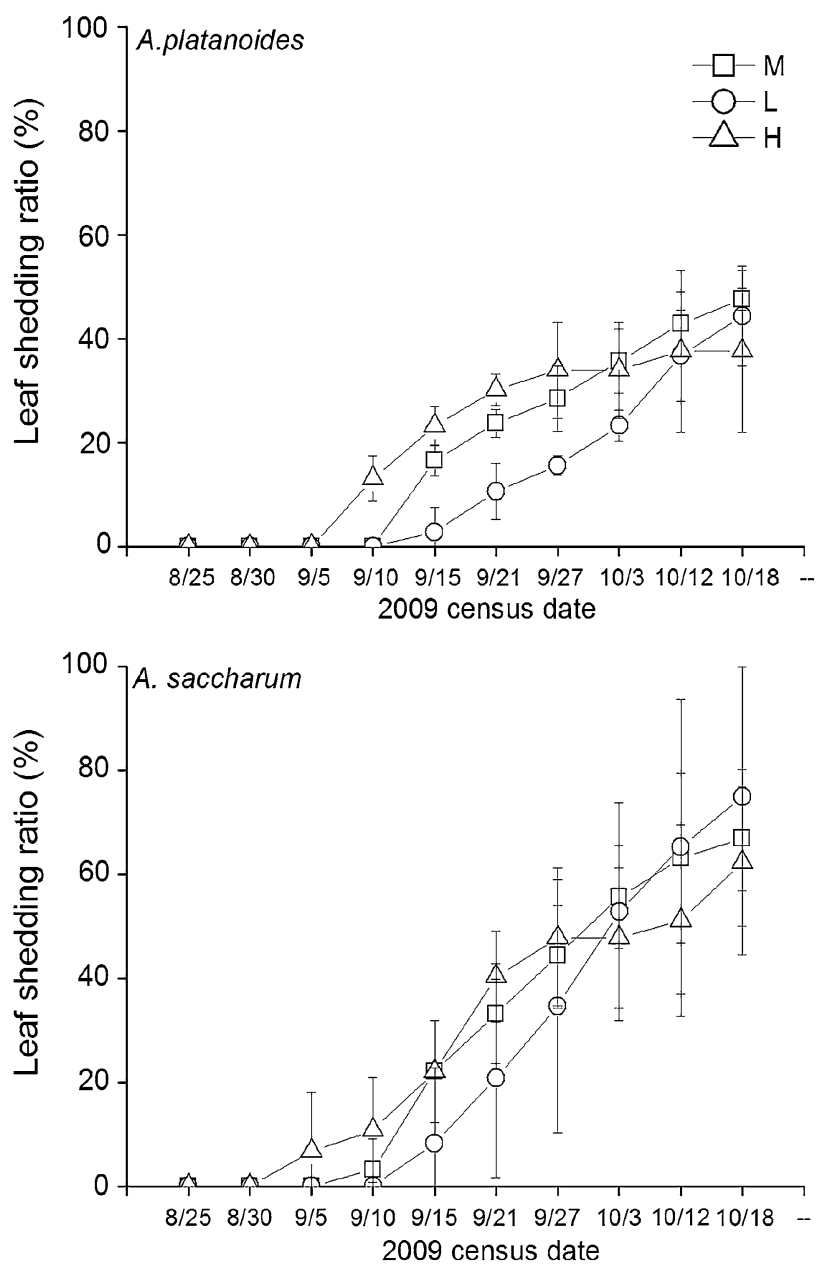

Fig. 6 Cumulative leaf shedding pattern in A. platanoides and A. saccharum at the first sampling dates (August 25-September 5), the second sampling dates (September 10-October 3) and the third sampling dates (October 12-18). Treatments: M, intermediate light ( $21 \%$ of full light); L, low light ( $4.9 \%$ of full light); $\mathrm{H}$, plants from intermediate light switched to the high-light environment. Each value is the mean of three plants, error bars are SE

tissue (Gould et al. 2002). Although the leaf anatomy in the test plants was not examined, it has been reported that anthocyanins accumulation in maples is mainly in the palisade mesophyll (Lee et al. 2003; van den Berg et al. 2009). This anthocyanins distribution pattern supports a role for light screening. We also observed that $A$. saccharum at greater risk of photoinhibition (low leaf $\mathrm{N}$ and limited photosynthetic capacity) during leaf senescence have higher anthocyanin, a pattern also supports the light screen hypothesis. Nevertheless, it appears that in spite of a large amount of de novo anthocyanin synthesis in senescing leaves, photoinhibition occurs in red and yellow maple leaves, when they are exposed to high-light levels. These results indicate that though anthocyanins may function as light screening, the anthocyanins in senescing maple leaves do not efficiently reduce light within the leaves as proposed
515

\begin{tabular}{|l|lll|}
\hline Journal : Large 11738 & Dispatch : 6-9-2014 & Pages : $\mathbf{1 2}$ \\
Article No. : $\mathbf{1 6 7 4}$ & $\square$ LE & $\square$ TYPESET \\
MS Code : ACPP-D-14-00009 & $\sim_{\text {CP }}$ & $\checkmark$ DISK \\
\hline
\end{tabular}


by van den Berg et al. (2009) that anthocyanins are not optimal internal light filters. The relative small anthocyanin concentrations, and anthocyanins present in the palisade mesophyll in maples (Ishikura 1973; Lee et al. 2003) than multiple locations throughout the palisade and spongy mesophyll in other wood species (Gould et al. 2002; Hughes et al. 2005; van den Berg et al. 2009) could explain that anthocyanins do not provide a physiologically significant level of photoprotection in maple leaves tested in our study.

Foliar $\mathrm{N}$ concentrations during the first and the second sampling periods were well within the $16.0-23.2 \mathrm{mg} \mathrm{g}^{-1}$ optimal range of Kolb and McCormick (1993) for A. saccharum. In contrast, $\mathrm{N}$ concentrations during third sampling date averaged only $6.0 \mathrm{mg} \mathrm{g}^{-1}$ under high-light conditions, which is far below the concentrations reported for A. saccharum seedlings with $\mathrm{N}$-limited growth (Walters and Reich 1997). The low-N leaves are more vulnerable to photoinhibitory risk (Schaberg et al. 2003), owning to the limited photosynthetic capacity. During the processes of leaf senescence, approximately $69-75 \%$ of the $\mathrm{N}$ in green leaves was resorbed in the both species. This represents higher resorption efficiency than the mean (50-52\%) reported for many plants (Chapin and Kedrowski 1983; Aerts 1996), but is consistent with previous measurements of resorption in Acer rubrum (Grizzard et al. 1976). As shown in Fig. 4d, $\mathrm{N}$ resorption efficiency did not differ significantly among leaves under low light and intermediate light in either species. However, $\mathrm{N}$ resorption was enhanced in high light.

We also observed a positive correlation between $\mathrm{N}$ resorption and anthocyanin concentrations in A. saccharum leaves (Fig. 5). One hypothesis is that anthocyanins protect foliar nutrient resorption by reducing oxidative stress and quenching free radicals sequestered in vacuoles during the chlorophyll degradation (Matile et al. 1999), as free radicals may disturb nitrogen and/or phosphorus resorption from leaves into branches (Lee et al. 2003). Accordingly, the antioxidant activity of high-light stressed leaves would be expected to exceed that of shaded ones. However, we observed that the antioxidant activity of leaves in the different light treatments was equal at all sampling periods. The results further suggest that rather than enhancing antioxidant capacity, anthocyanins may serve as a 'sunscreen' from excessive light in senescing leaves and reduce the risk of photo-oxidative damage, thus facilitating nutrient recovery as discussed in previous sections (Feild et al. 2001; Hoch et al. 2003). Nevertheless, we can not rule out the possibility that some other factor associated with high light, might be responsible for the increased nitrogen resorption. The results further suggest alternative strategies may be employed by senescing A. Platanoides leaves to compensate for less photoprotective function by anthocyanins. In addition to photoprotection, light intensity could also influence senescence and anthocyanin accumulation through sugar levels/sugar accumulation (Wingler et al. 2006, 2009), and future experiments should address the connection between leaf sugar levels, senescence regulation and photosynthetic protein degradation.

A recent study by Schaberg et al. (2008) demonstrated a relationship between foliar coloration and leaf retention strength and suggested that the orange-red coloration in $A$. saccharum may allow for an extended period of nutrient and sugar translocation compared with yellow leaves. In the present study, more leaves are shed between the first and second than between the second and third sampling period (Fig. 6), further strengthening the hypothesis that the benefits of anthocyanins may contribute to prolonged retention. Additionally, $\mathrm{N}$ concentration in the cell wall was nearly constant across different leaf color periods, which might help to maintaining leaves function (Takashima et al. 2004). We considered two possible explanations for red leaves being retained in high-light stressed plants. First, leaves would be retained as long as they have a positive carbon gain (Ackerly 1999). In September the total irradiance in Montreal is $\sim 74 \%$ of the maximum (July values) and in October it is still $\sim 40 \%$ (calculated from irradiation data from Plattsburgh New York about $70 \mathrm{~km}$ south). Therefore, the physiological gain of continued photosynthetic activity can be substantial. By increasing photoprotection and maintaining a photosystem during cold nights, trees could increase the length of their photosynthetically active period by a few weeks. This would concord with the relatively high rates of photosynthesis we still observed in the leaves at the second sampling dates (Fig. 2a). Second, we suggest that red leaves are involved in a conservative function as well, increasing $\mathrm{N}$ resorption and mean residence time during the third sampling dates, while other green or yellow leaves in maple trees are mainly involved in a photosynthetic function. Indeed extending the useful life of leaves comes at the risk of leaves freezing and dying before the tree could remove the nutrients therein.

Our results showed a higher N-resorption for high-light stressed plants contrasting to the suggestion of Hoch et al. (2003). A. saccharum in our study had greater anthocyanin accumulation in autumn leaves than A. Platanoides. Nevertheless, during the fall, A. saccharum and A. Platanoides only recovered different amounts of $\mathrm{N}$ at low light while at high light the two species show no difference in absorption. Additionally, it has been reported that differences in nitrogen allocation strategies between early and late successional species are important for nutrient resorption (Hoch et al. 2001). In this sense, the both maple species tested in our study behave similarly during autumn. The

\begin{tabular}{|l|lll|}
\hline Journal : Large 11738 & Dispatch : 6-9-2014 & Pages : 12 \\
Article No. : $\mathbf{1 6 7 4}$ & $\square$ & LE & TYPESET \\
MS Code : ACPP-D-14-00009 & $\checkmark_{\text {CP }}$ & $\checkmark$ DISK \\
\hline
\end{tabular}


higher resorption rates in our light-stressed trees are more difficult to explain. It could be that anthocyanins are overcompensating for the light stress or it could be that photosynthetic protection is the main function of anthocyanins and that the facilitation of nutrient resorption is of secondary importance. Yet, we hypothesize that anthocyanins' limited protection against photoinhibition, as several sets of data presented here argue some photoprotection could be assumed in autumn leaves. The association between anthocyanin production and the high-light environments, the prolonged retention of red leaves, the substantial physiological gain of continued photosynthetic activity in September at mid-northern latitudes as well as the links between anthocyanins and increased $\mathrm{N}$ resorption led us to assume that autumnal anthocyanins protect senescing foliage from photoinhibitory irradiances (although incomplete), and that leaf redness is a mechanism to squeeze a bit more photosynthesis out of the leaves before winter, allowing for the resorption of critical foliar nutrients to occur.

In conclusion, our results suggested that the one primary role of autumn anthocyanin is to protect the photosynthetic apparatus from photo-oxidative damage as light filters rather than as antioxidant, another major role is to extend carbon capture and help provide the energy needed for $\mathrm{N}$ resorption from senescing leaves in both A. saccharum and A. Platanoides during high-light stress. Nevertheless, we have realized that photoprotective capacity of anthocyanins were not able to compensate fully for the photoinhibitory stress, as the anthocyanins are not optimally located to efficiently reduce light within the leaves (van den Berg et al. 2009). Our results not only confirm earlier reports indicating a possible light screening role for leaf anthocyanins, but the data could also be useful for understanding the relationship between anthocyanins, photosynthesis and nutrient resorption during autumn for $A$. Platanoides and $A$. saccharum.

Author contribution Baoli Duan contributed to all the experimental process, conducting the experiment, dealing with the data and writing the paper. Alain Paquette coordinated the study and carried out the interpretation. Philippe Juneau, Jacques Brisson, Bastien Fontaine, and Frank Berninger mainly contributed to the experimental process. All authors have read and approved the final manuscript and have no conflicts of interest in regard to this research or its funding.

Acknowledgments We gratefully acknowledge funding by the Fonds québécois de la recherche sur la nature et les technologies (FQRNT) and the Youth Talent Team Program of the Institute of Mountain Hazards and Environment, CAS (SDSQB-2012-01). We also thank the Montreal Botanical Garden for providing the space necessary for this experiment.

\section{References}

Ackerly DD (1999) Self-shading, carbon gain and leaf dynamics: a test of alternative optimality models. Oecologia 119:300-310

Aerts R (1996) Nutrient resorption from senescing leaves of perennials: are there general patterns? J Ecol 84:597-608

Archetti M (2009) Classification of hypotheses on the evolution of autumn colours. Oikos 118:328-333

Björkman O, Demmig B (1987) Photon yield of $\mathrm{O}_{2}$ evolution and chlorophyll fluorescence characteristics at $77 \mathrm{~K}$ among vascular plants of diverse origins. Planta 170:489-504

Chapin FS, Kedrowski RA (1983) Seasonal changes in nitrogen and phosphorus fractions and autumn retranslocation in evergreen and deciduous taiga trees. Ecology 64:376-391

Chapin FS, Moilanen L (1991) Nutritional controls over nitrogen and phosphorus resorption from Alaskan birch leaves. Ecology 72:709-715

Esteban R, Fernández-Marín B, Becerril JM, García-Plazaola JI (2008) Photoprotective implications of leaf variegation in $E$. dens-canis $\mathrm{L}$. and $P$. officinalis L. J Plant Physiol 165:1255-1263

Feild TS, Lee DW, Holbrook NM (2001) Why leaves turn red in autumn. The role of anthocyanins in senescing leaves of redosier dogwood. Plant Physiol 127:566-574

Feng YL, Lei YB, Wang RF, Callaway RM, Valiente-Banuet A et al (2009) Evolutionary tradeoffs for nitrogen allocation to photosynthesis versus cell walls in an invasive plant. PNAS USA 106:1853-1856

Field C (1983) Allocating leaf nitrogen for the maximization of carbon gain: leaf age as a control on the allocation program. Oecologia 56:341-347

Fujiki T, Suzue T, Kimoto H, Saino T (2007) Photosynthetic electron transport in Dunaliella tertiolecta (Chlorophyceae) measured by fast repetition rate fluorometry: relation to carbon assimilation. J Plankton Res 29:199-208

Genty B, Briantais J-M, Baker NR (1989) The relationship between the quantum yield of photosynthetic electron transport and quenching of chlorophyll fluorescence. Biochimica et Biophys Acta 990:87-92

Gielen B, Löw M, Deckmyn G, Metzger U, Franck F et al (2007) Chronic ozone exposure affects leaf senescence of adult beech trees: a chlorophyll fluorescence approach. J Exp Bot 58:785-795

Gould KS, Vogelmann TC, Han T, Clearwater MJ (2002) Profiles of photosynthesis within red and green leaves of Quintinia serrata A. Cunn Physi Plant 116:127-133

Grizzard T, Henderson GS, Clebsch EEC, Reichle DE (1976) Seasonal nutrient dynamics of foliage and litterfall on Walker Branch, a deciduous forest ecosystem. ORNL/TM-5254, Oak Ridge National Laboratory, Oak Ridge

Hoch WA, Singsaas EL, McCown BH (2003) Resorption protection. Anthocyanins facilitate nutrient recovery in autumn by shielding leaves from potentially damaging light levels. Plant Physiol 133:1296-1305

Hoch WA, Zeldin EL, McCown BH (2001) Physiological significance of anthocyanins during autumnal leaf senescence. Tree Physiol 21:1-8

Hughes NM, Neufeld HS, Burkey KO (2005) Functional role of anthocyanins in high-light winter leaves of the evergreen herb Galax urceolata. New Phytol 168:575-587

Ishikura N (1973) The changes in anthocyanin and chlorophyll content during the autumnal reddening of leaves. Kumamoto $\mathrm{J}$ Sci Biol 11:43-50

Kolb TE, McCormick LH (1993) Etiology of sugar maple decline in four Pennsylvania stands. Can J For Res 23:2395-2402 
Kozlowski TT, Pallardy SD (1997) Physiology of woody plants. Academic Press, New York

Lee DW, O' Keefe J, Holbrook NM, Feild TS (2003) Pigment dynamics and autumn leaf senescence in a New England deciduous forest, eastern USA. Ecol Res 18:677-694

Lepeduš H, Gaća V, Viljevac M, Kovač S, Fulgosi H, Simić D, Jurković V, Cesar V (2011) Changes in photosynthetic performance and antioxidative strategies during maturation of Norway maple (Acer platanoides L.) leaves. Plant Physiol Bioch 49:368-376

Lev-Yadun S, Holopainen JK (2009) Why red-dominated autumn leaves in America and yellow-dominated autumn leaves in Northern Europe? New Phytol 183:497-501

Lichtenthaler HK, Buschmann C (2001) Chlorophylls and carotenoids: measurement and characterization by UV-VIS spectroscopy. Current protocols in food analytical chemistry. Wiley, New York, pp 431-438

Lu C, Zhang J (1998) Modifications in photosystem II photochemistry in senescent leaves of maize plants. J Exp Bot 49:1671-1679

Matile P, Hörtensteiner S, Thomas H (1999) Chlorophyll degradation. Annu Rev Plant Physiol Plant Mol Biol 50:67-95

Maxwell K, Johnson GN (2000) Chlorophyll fluorescence: a practical guide. J Exp Bot 51:659-668

May JD, Killingbeck KT (1992) Effects of preventing nutrient resorption on plant fitness and foliar nutrient dynamics. Ecology 73:1868-1878

McGrath R (1972) Protein measurement by ninhydrin determination of amino acids released by alkaline hydrolysis. Anal Chem 49:95-102

Mitchell AK (1998) Acclimation of Pacific yew (Taxus brevifolia) foliage to sun and shade. Tree Physiol 18:749-757

Miyazawa Y, Yahata H (2006) Is the parameter electron transport rate useful as a predictor of photosynthetic carbon assimilation rate? Bull Inst Trop Agr Kyushu Univ 29:39-53

Murray JR, Hackett WP (1991) Dihydroflavonol reductase activity in relation to differential anthocyanin accumulation in juvenile and mature phase Hedera helix L. Plant Physiol 97:343-351

Paquette A, Fontaine B, Berninger F, Dubois K, Lechowicz MJ, Messier C, Posada JM, Valladares F, Brisson J (2012) Norway maple displays greater seasonal growth and phenotypic plasticity to light than native sugar maple. Tree Physiol 32:1339-1347

Paquette A, Fontaine B, Messier C, Brisson J (2010) Homogeneous light regime in shade-house experiment overestimates carbon gains in Norway maple seedlings. J Hortic For 2:117-121

Park YI, Chow WS, Osmond CB, Anderson JM (1996) Electron transport to oxygen mitigates against the photoinactivation of Photosystem II in vivo. Photosynth Res 50:23-32
Perron MC, Juneau P (2011) Effect of endocrine disrupters on photosystem II energy fluxes of green algae and cyanobacteria. Environ Res 111:520-529

Pietrini F, Iannelli MA, Massacci A (2002) Anthocyanin accumulation in the illuminated surface of maize leaves enhances protection from photo-inhibitory risks at low temperature, without further limitation to photosynthesis. Plant, Cell Environ 25:1251-1259

Sanz-Pérez V, Pilar Castro-Díez P, Millard P (2009) Effects of drought and shade on nitrogen cycling in the leaves and canopy of Mediterranean Quercus seedlings. Plant Soil 316:45-56

Schaberg PG, Murakami PF, Turner MR, Heitz HK, Hawley GJ (2008) Association of red coloration with senescence of sugar maple leaves in autumn. Trees 22:573-578

Schaberg PG, van den Berg AK, Murakami PF, Shane JB, Donnelly JR (2003) Factors influencing red expression in autumn foliage of sugar maple trees. Tree Physiol 23:325-333

Takashima T, Hikosaka K, Hirose T (2004) Photosynthesis or persistence: nitrogen allocation in leaves of evergreen and deciduous Quercus species. Plant, Cell Environ 27:1047-1054

van den Berg AK, Perkins TD (2007) Contribution of anthocyanins to the antioxidant capacity of juvenile and senescing sugar maple (Acer saccharum) leaves. Funct Plant Biol 34:714-719

van den Berg AK, Vogelmann TC, Perkins TD (2009) Anthocyanin influence on light absorption within juvenile and senescing sugar maple leaves -do anthocyanins function as photoprotective visible light screens? Funct Plant Biol 36:793-800

Vergutz L, Manzoni S, Porporato A, Novais RF, Jackson RB (2012) Global resorption efficiencies and concentrations of carbon and nutrients in leaves of terrestrial plants. Ecol Monographs 82:205-220

Walters MB, Reich PB (1997) Growth of Acer saccharum seedlings in deeply shaded understories of northern Wisconsin: effects of nitrogen and water availability. Can J Forest Res 27:237-247

Wingler A, Masclaux-Daubresse C, Fischer AM (2009) Sugars, senescence, and ageing in plants and heterotrophic organisms. J Exp Bot 60:1063-1066

Wingler A, Purdy S, MacLean JA, Pourtau N (2006) The role of sugars in integrating environmental signals during the regulation of leaf senescence. J Exp Bot 57:391-399

Yasumura Y, Onoda Y, Hikosaka K, Hirose T (2005) Nitrogen resorption from leaves under different growth irradiance in three deciduous woody species. Plant Ecol 178:29-37

Zeliou K, Manetas Y, Petropoulou Y (2009) Transient winter leaf reddening in Cistus creticus characterizes weak (stress-sensitive) individuals, yet anthocyanins cannot alleviate the adverse effects on photosynthesis. J Exp Bot 60:3031-3042

\begin{tabular}{|l|lll|}
\hline Journal : Large 11738 & Dispatch : 6-9-2014 & Pages : $\mathbf{1 2}$ \\
Article No. : $\mathbf{1 6 7 4}$ & $\square$ LE & $\square$ TYPESET \\
MS Code : ACPP-D-14-00009 & $\sim_{\text {CP }}$ & $\checkmark$ DISK \\
\hline
\end{tabular}


Journal : 11738

Article : 1674

\section{Author Query Form}

\section{黛 Springer}

the language of science

\section{Please ensure you fill out your response to the queries raised below and return this form along with your corrections}

\section{Dear Author}

During the process of typesetting your article, the following queries have arisen. Please check your typeset proof carefully against the queries listed below and mark the necessary changes either directly on the proof/online grid or in the 'Author's response' area provided below

\begin{tabular}{|l|l|l|}
\hline Query & Details Required & Author's Response \\
\hline AQ1 & $\begin{array}{l}\text { The given sentence seems to be incomplete. 'For both species, a125bove ...' Please check for missing } \\
\text { words/phrases and complete the sentence. }\end{array}$ & \\
\hline
\end{tabular}

